\title{
Socio-Economic Characteristics and Level of Awareness and Perception on Reducing Emissions from Deforestation and Forest Degradation Programme (REDD+) by Rural Communities in Akure Forest Reserve, Nigeria
}

\section{${ }^{* 1}$ ADEKUGBE, OA; ${ }^{1}$ OYERINDE, OV ; ${ }^{2}$ OLUWAJUWON, TV ; ${ }^{3}$ ABISOYE, TR; ${ }^{4}$ ATANDA, TA}

\author{
${ }^{I^{*}}$ Forestry Research Institute of Nigeria, Jericho, Ibadan, Nigeria \\ ${ }^{I}$ Department of Forestry and Wood Technology, Federal University of Technology, Akure, Ondo State, Nigeria \\ ${ }^{2}$ School of Natural Sciences, Bangor University, Bangor, UK \\ ${ }^{3}$ World Ecological Concept Limited, Ibadan, Nigeria \\ ${ }^{4}$ Forestry Research Institute of Nigeria, Jericho, Ibadan \\ *Corresponding Author Email: adekugbeoluwaseun@gmail.com; other Authors Email: ovoyerinde@futa.edu.ng. \\ tomiwaoluwajuwon@gmail.com; abisoyetemitope5@gmail.com; atandatoyeeb@gmail.com
}

\begin{abstract}
Rural communities around Akure forest reserve depend mostly on forest and its products for their livelihoods, which results in its high rate of deforestation. Meanwhile, the Reducing Emissions from Deforestation and forest Degradation programme (REDD+), one of the international forest-governance initiatives to address sustainable forest management and climate change mitigation has been introduced to the reserve. This research investigated the socio-economic status of the communities in Akure forest reserve, level of dependence on the forest resources and their level of awareness and perception about the REDD+ project. Six communities were selected randomly from around the reserve which were in the readiness phase of the REDD+ project. Data were collected through household survey with the use of semi-structured questionnaire administered to 120 respondents (household heads) selected randomly from the communities as well as information from 6 key informants (village heads). Descriptive Statistics and Chi Square test were used in the analysis of the data and the result showed that the main income-generating activity in the communities was farming accounting for $70.8 \%$ of the respondents. This affirms that the high level of the households' dependence on forest resources is traceable to their socio-economic characteristics. Considering the level of awareness of REDD+ project, results revealed that the level of awareness of the key informants about REDD+ was very high $(83.3 \%)$ while it was very low at the local community level with only $35 \%$ of the respondents being aware of the REDD + project among which $23.3 \%$ found it beneficial. Therefore, to enhance the level of effectiveness of REDD+ project implementation, there should be an increase in the level of awareness in the communities.
\end{abstract}

DOI: https://dx.doi.org/10.4314/jasem.v24i11.10

Copyright: Copyright (C) 2020 Adekugbe et al. This is an open access article distributed under the Creative Commons Attribution License (CCL), which permits unrestricted use, distribution, and reproduction in any medium, provided the original work is properly cited.

Dates: Received: 20 September 2020; Revised: 29 October 2020; Accepted: 10 November 2020

Keywords: Forest Communities, Awareness, REDD+ Project, Rural livelihood, Deforestation

Forest is a valuable environmental and economic resource that supports natural systems and human welfare (Ajake and Enang, 2012). Rural communities around the world depend on forests for their livelihoods, not just for food but also for fuel, income, and livestock grazing areas, collection of wood and non-wood forest products (Banerjee and Madhurima, 2013). The huge dependence on forest for rural livelihood led deforestation to be common in most of the developing world. This is due to various drivers such as clearing forest lands for farming, collection of timber and non-timber forest products, high poverty level and the increasing human population (Stephenson, 2011). (Vedeld et al., 2005) reported that most of the rural households depend on forests directly for timber, non-timber products, and indirectly for things such as air and water quality, biodiversity preservation, carbon sequestration, and other ecological services. Thus, forest products remain an important source of income and livelihood for the rural communities throughout the developing world, especially in Sub-Saharan Africa. In Nigeria, most of rural households depend on agriculture income, which is directly or indirectly dependent on forests. The 15 th Conference of the Parties (COP15) of the United Nations Framework Convention on Climate Change (UNFCCC) decided that reducing emissions from deforestation and forest degradation (REDD+) would be the mitigation strategy to slow down the rate of deforestation with a focus on conserving and enhancing carbon stocks through sustainable forest management. Until now, over fifty high carbon value countries have been supported by the World Bank Forest Carbon Partnership Facility (FCPF) or by the 
United Nations Collaborative Programme on REDD+ (UN-REDD) in their REDD+ implementation (IPCC, 2007). Nigeria has launched works on various REDD+ streams notably on socio-environmental safeguards, multiple ecosystem benefits, participatory governance assessment for REDD+, and enhanced capacities for UNFCCC reporting as part of developing and finalizing its proposal (Federal Ministry of Environment, 2011). However, the country has been experiencing high rate of deforestation and forest degradation having lost about $79 \%$ of her primary forests between 1990 and 2005 and an average of $11 \%$ per year since 2000 (FAO, 2005). Particularly, Akure forest reserve which is the study site for this research has lost almost all the vegetation cover leaving about $32.1 \%$ of her undisturbed forest as at 2017 (Gbiri and Adeoye, 2019). Hence, the introduction of a REDD+ project into the Reserve will reduce deforestation/degradation factors, improve the forest conditions, and enhance the community livelihoods in the forest area. The Nigeria REDD+ Programme is put in place at the Federal Ministry of Environment and has established a pilot REDD+ programme in Cross River State. The Ondo State REDD+ has now moved from the readiness stage and about to the implementation phase. Basically, before project implementation, it is necessary to assess the socioeconomic status of the forest communities and the dependence of the people on the forest and also the level of awareness of the project and the perception of the members of the community in order to come up with reflective information about the factors that might influence the adoption of REDD + by the rural communities. Presently, there is no sufficient information on the socio-economic impact of the programme in Ondo State (Federal Ministry of Environment, 2011). Therefore, there is a need to provide sufficient evaluation required to help the officials of the REDD+ programme to inform the best design and facilitate smooth implementation of its projects, towards the reduction of deforestation without jeopardizing the accessibility of its co-benefits to the forest-dependent communities. This research therefore aimed to provide information on the socioeconomic characteristics of the people in the forest communities in Akure forest reserve and the level of awareness and perception on Reducing Emissions from Deforestation and Forest Degradation Programme (REDD+) project in the state.

\section{MATERIALS AND METHOD}

Study Area: Akure Forest Reserve is situated between Aponmu and Obada communities in Akure South Local Government of Ondo State, Nigeria at latitudes $7^{\circ} 16^{\prime} 41.77 \mathrm{~N}$ and longitudes $5^{\circ} 2^{\prime} 2.01 \mathrm{E}$. The strict nature reserve (Queen's plots) as shown in (Fig. 1), is a part of the Reserve and was instituted in 1948, covering an area of about 32 hectares (Adeduntan, 2009); established with a view to preserving the genetic diversity of the forest ecosystem.

Akure forest reserve has a tropical climate with prominent wet and dry seasons: the rainy season and the dry season. The rainy season generally occurs between March and October while the dry season occurs between November and February yearly. Also, the mean annual temperature is about $26^{\circ} \mathrm{C}$ (minimum $19^{\circ} \mathrm{C}$ and maximum $34^{\circ} \mathrm{C}$ ) (Adekunle et al., 2013; Adesuyi et al., 2020).

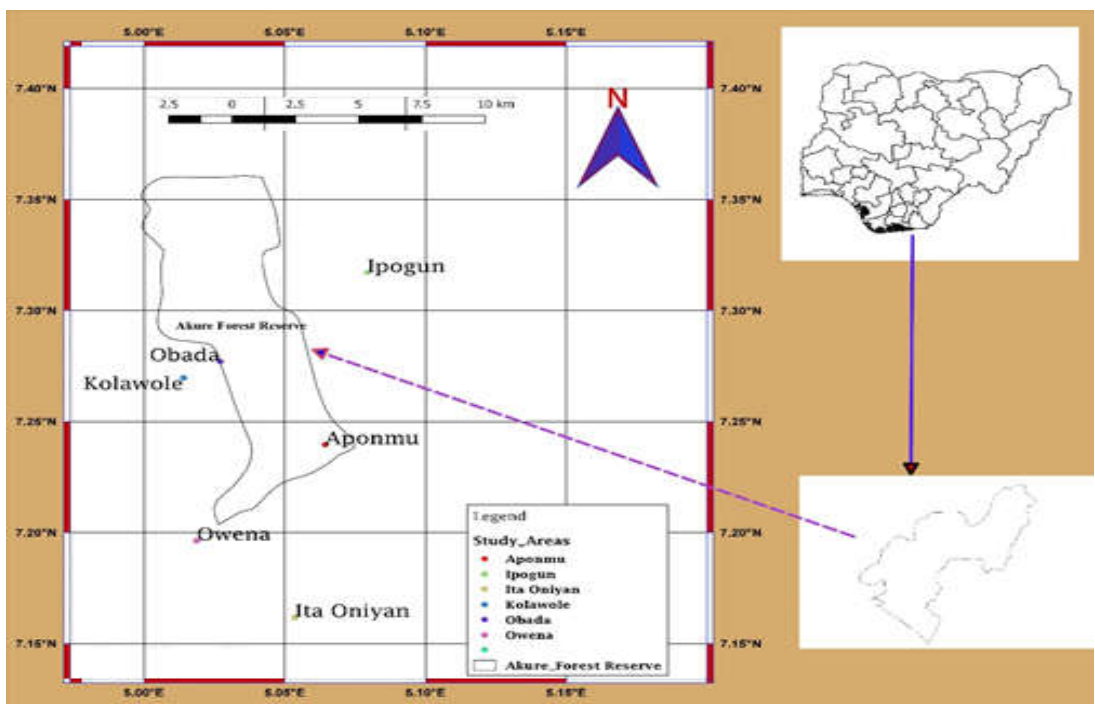

Fig 1: Map of Akure Forest Reserve showing the sampled communities. Source: Field Survey, 2019 
Data Collection and Analysis: The primary data were collected with the use of semi-structured questionnaire and in-depth interview of key informants. Six communities within and around Akure Forest Reserve, which included Obada, Aponmu, Ipogun, Itaoniyan, Owena and Kolawole, were selected from the study area based on the involvement at the REDD+ readiness phase.

Questionnaires were administered to (120) people from the (6) communities to gather information on the socioeconomic characteristics of the households including their means of livelihood, the level and impacts of their dependence on the forest and their awareness about the REDD+ programme.

Data Analysis: Data collected from the field were analysed using Statistical Package for Social Sciences (SPSS) and results were presented in tables. Chi Square analysis was carried out to test for association among the demographic characteristics of the respondents and the level of awareness of the REDD+.

\section{RESULTS AND DISCUSSION}

Socio-economic Characteristics of the Respondents: Out of the respondents from the six sampled communities, majority were male $(67.5 \%)$ while $32.5 \%$ were female in the six communities. In terms of education, $41.7 \%$ of the respondents had no level of formal education while $30.8 \%$ had primary education, $2.5 \%$ had adult education, $24.2 \%$ had secondary education and only $0.8 \%$ had tertiary education, respectively. Also, (Table 1) shows that majority of the respondents $(70.8 \%)$ depended on crop farming as their source of livelihood which translates to being their primary occupation in the rural communities and contributes to forest encroachment/degradation, while civil servants were the minority $(1.7 \%)$ in the communities. The descriptive statistics of the age, household size and average annual income of the respondents is shown in (Table 2). It was deduced that the minimum age of the respondents was 30 years and the maximum age was 75 years. The values recorded for the household size were between 2 and 14, while it was obtained that the least and highest annual incomes earned by the locals were $\$ 300,000$ and $\$ 1,500,000$ respectively.

Table 1: Demographic characteristics of the respondents

\begin{tabular}{lll}
\hline Variable & \multicolumn{2}{c}{ Frequency Percentage (\%) } \\
\hline Gender & 81 & 67.5 \\
Male & 39 & 32.5 \\
Female & & \\
\hline Level of education & \\
No formal education & 50 & 41.7 \\
Adult education & 3 & 2.5 \\
Primary education & 37 & 30.8 \\
Secondary education & 29 & 24.2 \\
Tertiary education & 1 & 0.8 \\
\hline Main sources of livelihood & & \\
Businesg/Selling agriculture products & 28 & 23.3 \\
Civil servant & 2 & 1.7 \\
Crop farming & 85 & 70.8 \\
Artisan & 5 & 4.2 \\
\hline
\end{tabular}

Source: Field Survey, 2019

Table 2: Descriptive statistics showing the age, household size and annual income of the respondents

\begin{tabular}{lllll}
\hline & N & Min. & Max. & Mean \pm STD \\
\hline Age & 120 & 30 & 75 & $51.61 \pm 9.424$ \\
Household Size & 120 & 2 & 14 & $6.55 \pm 2.590$ \\
Annual Income $\approx$ ) & 120 & 300,000 & $1,500,000$ & $430353.75 \pm 1660065.26$ \\
\hline \multicolumn{5}{c}{ Source: Field Survey, 2019 }
\end{tabular}

Poverty Analysis of the Forest-dependent Households: Rural poverty can be directly linked to the decline of forest cover and resources (Pandey, 1996).

The poverty threshold for an individual has been fixed as of $\$ 1.90$ ( $\$ 737.2)$ per day (World Bank, 2015). Based on the respondents' incomes, the analysis of the households in the communities around Akure forest reserve is presented in (Table 3 ).
The study showed that majority $(75.8 \%)$ of the respondents was living below the poverty line in the study communities while only $24.2 \%$ lived above it. 
Association among Socio-economic, Forest Resources Use and REDD+: The result indicated no significance in the level of association between gender and forest resource uses as the $P$ value was .87 . Similarly, the $P$ value (.21) obtained from the association between gender and collection of wood and non-wood products was also not significant. Conversely, the levels of association between gender and each of information about REDD + and perspective about REDD + had $P$ values of .045 and .032 which revealed that the project's adoptability may significantly vary with gender. However, no significant was found between age and each of collection of wood and non-wood products, as well as between forest resource use and perspective about REDD+ with $P$ values of $.87, .090$ and .78 respectively. This suggests that forest resource use and REDD+ perspective are not influenced by the age categories of the forest-dependent people.

Table 4: Level of association between the socio-economic characteristics and forest resource use. Source: Field Survey, 2019

\begin{tabular}{lllll}
\hline & \multicolumn{2}{l}{ Chi-Squared } & $\boldsymbol{P}$ - \\
Variable & $(\mathbf{x} \mathbf{2})$ & Value & Remarks \\
\hline Gender*Forest resource use & $.269 \mathrm{a}$ & .87 & $\mathrm{NS}$ \\
Gender*Collection of wood and non-wood products & $1.55 \mathrm{la}$ & .21 & $\mathrm{NS}$ \\
Gender*Information about REDD+ & $4.030 \mathrm{a}$ & .045 & 8 \\
Gender*Perspective about REDD+ & $8.805 \mathrm{a}$ & .032 & 8 \\
Age*Collection of wood and non-wood products & $.271 \mathrm{a}$ & .87 & $\mathrm{NS}$ \\
Age*Forest resource use & $8.047 \mathrm{a}$ & .090 & $\mathrm{NS}$ \\
Age*Perspective about REDD+ & $3.201 \mathrm{a}$ & .78 & $\mathrm{NS}$ \\
\hline
\end{tabular}

Access and Level of Dependence of the Communities on Forest Resources: The means of access and level of dependence of the study communities on forest resources are presented in (Table 5). More than half of the respondents $(60.8 \%)$ accessed the forest by feet consequent upon their socioeconomic status, $36.7 \%$ through motorcycle, $1.7 \%$ through bicycle and the least $(0.8 \%)$ by car. Basically, majority of the respondents of about $71.7 \%$ did not need permit to collect forest resources from the forest while relatively few of the respondents (about 28\%) needed permit before being allowed to collect forest resources. While confirming the level of importance of the forest to the locals, $65.8 \%$ of the respondents acknowledged that the forest resources frequently obtained were very important, $32.5 \%$ supported its importance as being normal while only $1.7 \%$ of the respondents indicated that the forest resources were less important. Meanwhile, majority of them depended on clearing forest lands for farming (99.2\%).

Table 5: Access and dependence on forest resources among the respondents in the reserve

\begin{tabular}{lll}
\hline Variable & Frequency & Percentage (\%) \\
\hline Access to forest & 73 & 60.8 \\
By feet & 1 & 0.8 \\
By car & 2 & 1.7 \\
By bicycle & 44 & 36.7 \\
By motorcycle & \\
\hline Permit needed for the collection of forest & \\
Products & 34 & 28.3 \\
Yes & 86 & 71.7 \\
No & 2 & \\
\hline Importance of forest resources & 1.7 \\
Less important & 39 & 32.5 \\
Important & 79 & 65.8 \\
Very important & & \\
\hline Involvement in the collection of wood & 110 & 91.7 \\
and non-wood wood forest product & 10 & 8.3 \\
Yes & \\
No & 119 & 99.2 \\
\hline Dependence on clearing forest lands for farming & \\
Yes & 1 & 0.8 \\
No & Source: Field Survey, 2019 & \\
\hline
\end{tabular}

Forest Resource Uses among the Respondents: The communities within and around Akure forest reserve basically used the forest resources as presented in
(Table 6). Majority of the respondents in the communities amounting to $67.5 \%$ collected fuel wood from the forest and $30.8 \%$ collected Non-Timber 
Forest Products (NTFPs) from the forest while relatively few (1.7\%) grazed their livestock on forest lands as a means of benefiting from the forest resources.

Table 6: Forest resources use among the respondents in the communities

\begin{tabular}{lll}
\hline Variable & Frequency & Percentage (\%) \\
\hline Collection of fuel wood & 81 & 67.5 \\
Collection of NTFPs & 37 & 30.8 \\
Grazing Livestock on forest lands & 2 & 1.7 \\
\hline
\end{tabular}

Knowledge, Awareness and Perspective of the Communities about REDD+: The level of knowledge, awareness and readiness about REDD + of both the key informants (village heads) and the respondents (communities' members) in Akure forest reserve were reported in (Table 7). The largest number $(83.3 \%)$ of the village heads in the rural communities around the forest reserve already had information about the REDD+ project while only $16.7 \%$ were uninformed. On the other side, a relatively high number $(65 \%)$ of the respondents in the communities were just getting to hear about REDD+ project for the first time. Similarly, the REDD+ awareness was high among the key informants as $66.7 \%$ indicated it to be very good, while such awareness was observed to be very poor among the members of the communities (54.17\%). Finally, $66.7 \%$ of the key informants in Akure forest reserve acknowledged that the REDD + project will be highly beneficial while $65.83 \%$ of the members lacked idea about its beneficialness. This trend implies a lack of proper communication of what the REDD+ project is, by the heads, to the community members.

Table 7: Knowledge and awareness about REDD+ project among the key informants and the respondents in Akure forest reserve

\begin{tabular}{|c|c|c|c|c|}
\hline \multirow{2}{*}{$\begin{array}{l}\text { Variable } \\
\text { Information about REDD+ } \\
\text { Yes } \\
\text { No }\end{array}$} & \multicolumn{2}{|c|}{$\begin{array}{l}\text { Key } \\
\text { informants } \\
\text { Frequency } \\
\text { Percentage (\%) }\end{array}$} & \multicolumn{2}{|c|}{$\begin{array}{l}\text { Respondents } \\
\text { Frequency } \\
\text { Percentage (\%) }\end{array}$} \\
\hline & $\begin{array}{l}5 \\
1 \\
\end{array}$ & $\begin{array}{l}83.3 \\
16.7\end{array}$ & $\begin{array}{l}42 \\
78\end{array}$ & $\begin{array}{l}35 \\
65\end{array}$ \\
\hline $\begin{array}{l}\text { REDD+ Awareness } \\
\text { Good } \\
\text { Very good } \\
\text { Poor }\end{array}$ & $\begin{array}{l}2 \\
4 \\
-\end{array}$ & $\begin{array}{l}33.3 \\
66.7 \\
-\end{array}$ & $\begin{array}{l}20 \\
35 \\
65\end{array}$ & $\begin{array}{l}16.67 \\
29.16 \\
54.17\end{array}$ \\
\hline $\begin{array}{l}\text { Perspective about REDD+ } \\
\text { Beneficial } \\
\text { Very beneficial } \\
\text { Maybe beneficial } \\
\text { I don't know }\end{array}$ & $\begin{array}{l}2 \\
4 \\
- \\
-\end{array}$ & $\begin{array}{l}33.3 \\
66.7 \\
- \\
-\end{array}$ & $\begin{array}{l}10 \\
28 \\
3 \\
79\end{array}$ & $\begin{array}{l}8.33 \\
23.33 \\
2.5 \\
65.83\end{array}$ \\
\hline
\end{tabular}

The impacts of forest resources as a predictor to the potential implications of the REDD+ project on rural livelihoods as well as the awareness of the project in Akure forest reserve, Ondo State, Nigeria were revealed in this study. It was obtained that there is a high level of dependence on forest resources for their livelihoods. Majority of the respondents depend on forest resources across all age groups and gender, with the collection of fuel wood constituting the highest forest resource use in the communities. Similarly, these rural people explore forest reserve for NTFPs, and a part of its land has been converted to a grazing ground for their livestock. This high level of dependence on forest resources observed in the study communities is traceable to their high poverty level, as indicated by the poverty line, with an average household size of 7 earning approximately $\$ 430,000$ naira annually. This further gives credence to the assertion by (Chao, 2012) that people who live adjacent to forest lands depend largely on the forests for their subsistence, and this could have consequently resulted to the deforestation and forest degradation in the Akure forest reserve which was reported by (Gbiri and Adeoye, 2019). The variation in the dependence and use of forest resources, as shown in Table 5, also found a base in the report of (Stephenson, 2011) that many people around the world depend on forests, not just for food but also for fuel, income, livestock grazing on forest lands, and collection of medicinal plants, all in varying degrees. However, there has been a high precedence of farming within the forest reserve lands evident by the majority $(70.8 \%)$ of the respondents having it as their major source of livelihoods. This level of agricultural activities confirms the aerial cover study of the reserve (Gbiri and Adeoye, 2019), which reported a 5.2\%-increase in farmland, hence, constituting a major deforestation driver in the reserve. In addition, this finding corroborates that of (Appiah et al., 2009) in Ghana, who reported that farming for livelihood remains the 
largest deforestation factor in the country. Consequently, it can be deduced that the socioeconomic characteristics of the communities dictate the nature and extent of their dependence on forest resources for livelihood, as supported by (Jindal et al., 2018) and (Chia et al., 2013). Basically, rural poverty and underdevelopment are predominant in the study communities as the majority $(75.8 \%)$ of the respondents have been confirmed to be living below the poverty line with no observable social amenities. Typically, Obada and Kolawole communities lacked access to electricity and good transportation network. This can be directly linked to the high (67.5\%) dependence on the forest reserve for collection of fuel wood by the rural households in a bid to provide energy. As a result of the poor electricity supply and high poverty level experienced by the forest communities, the locals have been put at a disadvantage of securing alternative cooking and lighting options. Similarly, (Abdallah and Monela, 2007) have earlier concluded that people are forced to use wood fuel because of the lack of national electricity grid. Meanwhile, such increasing fuelwood consumption has been a significant factor of largescale deforestation. On the other hands, lack of sufficient road network has not only affected the socioeconomic status of the people by limiting them to involve mainly in farming practices (occupation) but has also contributed to their low agricultural productivity. Despite the long distance to the forest farms, they continually access it by trekking with no automobiles, hence reducing their outputs at the expense of increasing forest lands' encroachment by the farmers. All these suggest that, creating an alternative means of livelihood opportunities for the study communities and improving their rural welfare could help in reducing rural dependence on the said forest reserve (Banerjee and Madhurima, 2013).This can therefore, be facilitated by proper implementation of the benefit-sharing mechanism of REDD + which has the potential positive impacts and co-benefits such as forest-tenure improvement, provision of income diversification, improvement of local infrastructure, development of human capital, strengthening of social capital, job creation, amongst others (Bayrak and Marafa, 2016). However, majority $(65.83 \%)$ of the respondents claimed that they do not know if the $\mathrm{REDD}+$ project is beneficial. This response is traceable to the lack of awareness about the REDD+ project in the study communities as earlier shown in the assessment result about its awareness, where a large number $(65 \%)$ of them confirmed their oblivion about the project. Conversely, this was not the case with the key informants where $83.3 \%$ were aware and knew about the REDD+ project. This suggests that information is not uniformly disseminated among the study populace. Meanwhile, it was observed that only the villages' heads, constituting majority of the key informants, had the opportunity to receive first-hand information and orientation about the project given by the REDD+ team, but must have failed to properly inform the members of the communities, hence will hinder local community participation. This totally agrees with (Samndong, 2018) who reported the insufficiency of information dissemination during the introduction process as well as the non-democratic decision-making process about the REDD+ pilot project in Congo (DRC). However, drawing from an understanding that the key role of community members in the success of an intervention cannot be invalidated, it is essential that increased effort is channelled into education, awareness, and subsequent engagement of the concerned communities in Akure forest reserve about the REDD+ project. This will consequently facilitate the transfer of knowledge and behavioural change on how the communities relate with the forest reserve, without depriving them of the potential beneficial impacts of the project on their livelihood.

Conclusion: The household's dependence on forest resources can be closely linked to their socioeconomic needs and characteristics. This affirms the importance of forest resources to the communities in Akure forest reserve. Thus, aligning and monitoring the REDD+ intervention to addressing the livelihoods of the forest-dependent communities will greatly enhance the adoption, implementation and effectiveness of the REDD+ project. To facilitate this, more awareness about the project has to be promoted within the community and also enhance their perception about the project through extension programmes.

\section{REFERENCES}

Abdallah, JM; Monela, GG (2007). Overview of Miombo woodlands in Tanzania: Indigenous tree species for ecosystem restoration and wood production in semi-arid Miombo woodlands in Eastern Africa. Proceedings of the first MITMIOMBO Project workshop held in Morongo, Tanzania, pp.6-12.

Adeduntan, SA (2009). Influence of human activities on diversities and abundance of insects in Akure Forest Reserve, Ondo State, Nigeria. Int. J. Bio. Chem. Sci. 3(6): 1320-1335.

Adekunle, VAJ; Olagoke, AO; Ogundare, AF (2013). Logging impacts in tropical lowland humid forest on tree species diversity and environmental 
conservation. Appl. Ecol. Environ. Res. 11(3): 491511.

Adesuyi, FE; Akinbowale, AS; Olugbadieye, OG; Jayeola, K (2020). Fitting non-linear models for tree volume estimation in strict nature reserve, South-West, Nigeria. Trop. Plant Res. 7(1): 06-13.

Ajake, AO; Enang, EE (2012). Demographic and socio-economic attributes affecting forest ecosystem exploitation and management in the rural communities of Cross River State, Nigeria. Am. Int. J. Contemp. Res. 2(1):111-123.

Appiah, M; Blay, D; Damnyag, L; Dwomoh, FK; Pappinen, A; Luukkanen, O (2009). Dependence on forest resources and tropical deforestation in Ghana. Environ. Dev. Sustain. 11: 471-487

Banerjee, A; Madhurima, C (2013). Forest degradation and livelihood of local communities in India: A human rights approach. J. Hortic. For. 5(8): 122129.

Bayrak, MM; Marafa, LM (2016). Ten years of REDD+: A critical review of the impact of REDD+ on forest-dependent communities. Sustainability 8: 620 .

Chao, S (2012). Forest people: Numbers across the world. Forest Peoples Program, Moreton-inMarsh, UK.

Chia, EL; Somorin, OA; Sonwa, DJ; Tiani, AM (2013). Local vulnerability, forest communities and forest carbon conservation: case of southern Cameroon. Int. J. Biodivers. Conserv. 5: 498-507.

FAO (2005). State of the world's forests: Food and Agriculture Organization of the United Nations, Rome.

ftp://ftp.fao.org/docrep/fao/007/y5574e/y5574e00. pdf.

Federal Ministry of Environment (2011). A preliminary assessment of the context for REDD in Nigeria. Commissioned by the Federal Ministry of Environment, the Cross-River State's Forestry Commission and UNDP.
Gbiri, IA; Adeoye, NO (2019). Analysis of pattern and extent of deforestation in Akure Forest Reserve, Ondo State, Nigeria. J. Environ. Stud. Sci. 12(12):1-11

IPCC (2007). Climate change mitigation. Contribution of working group III to the fourth assessment report of the Intergovernmental Panel on Climate Change; Ed; Metz et al., Cambridge University Press, Cambridge, pp.498-540.

Jindal, R; Kerr, JM; Carter, S (2018). Reducing poverty through carbon forestry? Impacts of the N'hambita community carbon project in Mozambique. World Dev. 40(10): 2123-2135.

Pandey, S (1996). Deforestation and rural poverty in developing countries: the role of social work. $J$. Sociol. Soc. Welf. 23(1): 8.

Samndong, R (2018). The participation illusion: questioning community participation in a REDD+ pilot project in the Democratic Republic of Congo. Int. For. Rev. 20: 390-404

Stephenson, S (2011). Does ODA grow on trees? A legal analysis of REDD+ ODA finance. Eur. J. Leg. Stud. 4(1): 81-101.

Vedeld, P; Angelsen, A; Sjaastad, E; Kobugabe Berg, $G$ (2004). Counting on the environment: forest environmental incomes and the rural poor. Environment Department. The World Bank, Washington DC, p.24.

World Bank (2006). Unlocking opportunities for forest dependent people in India. World Bank, South Asia Region, p. 85 .

World Bank (2015). Global poverty line update. The World Bank, Washington DC 